\title{
ELASTIC PROPERTIES OF ROCKS
}

\author{
Karagianni A. ${ }^{1}$, Karoutzos G. ${ }^{1}$, Ktena S. ${ }^{1}$, Vagenas N. ${ }^{1}$, Vlachopoulos I. ${ }^{1}$, \\ Sabatakakis N. ${ }^{1}$ and Koukis G. ${ }^{1}$ \\ ${ }^{1}$ University of Patras, Department of Geology, Section of Applied Geology and Geophysics, Laboratory of \\ Engineering Geology, 26500 Patras, Greece
}

\begin{abstract}
The aim of this paper is to determine the elastic parameters of some rocks and especially limestones, schist, sandstones, conglomerates, peridotites and granites using a large number of laboratory tests performed on intact rock samples. The range of values for Young 's modulus and uniaxial compressive strength is evaluated, while the relationship between elastic and strength parameters is defined. Regression analyses were applied to define relations among these parameters and the range of values of modulus ratio $(M R)$ is estimated for each rock type.
\end{abstract}

Key words: Young's modulus, uniaxial compressive strength, modulus ratiodeformability, laboratory testing.

\section{Introduction}

Deere and Miller (1966) proposed the classification of intact rock based on the ratio of tangent modulus of elasticity, $\mathrm{E}_{\mathrm{t}}$, to unconfined compressive strength $\left(\sigma_{\mathrm{c}}\right)$ in five classes, from A (very high modulus ratio, $\mathrm{E}_{\mathrm{t}} / \sigma_{\mathrm{c}}>500$ ) to $\mathrm{E}$ (very low modulus ratio, $\mathrm{E}_{\mathrm{t}} / \sigma_{\mathrm{c}}<50$ ) respectively.

Hoek and Diederichs (2006) used this modulus ratio, calling this MR, along with the GSI value of the rock mass classification in order to estimate the rock mass deformation modulus, $\mathrm{E}_{\mathrm{rm}}$, giving general guidelines for the selection of MR values in the case of lack of experimental data.

In this paper the range of MR values for some representative Greek rocks is estimated and the obtained values are compared with those proposed by Hoek and Diederichs (2006) regarding GSI application.

\section{Test procedure}

A number of block samples were obtained from different outcrops of rocks formations. The sampling locations were widely distributed around the Greek territory. Laboratory core drill and saw machines were used to cut the samples and end faces in order to provide cylindrical specimens in size, shape and ends geometries according to testing requirements. The specimen size was $54 \mathrm{~mm}(\mathrm{NX})$ to 80 $\mathrm{mm}$ in diameter with a length to diameter ratio of 2.0 to 2.5. The execution of laboratory tests on intact rock material was in accordance with I.S.R.M. suggested methods (1981) and A.S.T.M. standards (D 3148-93). More specifically, the parameters of rocks specimens determined by tests carried out in laboratory, in dry conditions for a better comparison of the results, were uniaxial compressive strength ( UCS- $\sigma \mathrm{c}$ ), and $\mathrm{E}_{\mathrm{t}}$ (elastic Young`s modulus). Finally, laboratory tests were conducted in more than 200 intact rock specimens. 
Table 1. Results of intact rock elastic parameters

\begin{tabular}{|c|c|c|c|}
\hline Results and statistical parameters & $\sigma_{c}(M P a)$ & $E_{t}(M P a)$ & $M R=E_{t} / \sigma_{c}$ \\
\hline \multicolumn{4}{|l|}{ schist } \\
\hline Minimum value (Min) & 5.2 & 2000 & 134 \\
\hline Maximum value (Max) & 94.0 & 44000 & 920 \\
\hline Mean value (Mean) & 32.5 & 12690 & 445 \\
\hline Standard deviation (Std dev) & 20.2 & 10286 & 230 \\
\hline Number of samples (n) & 31 & 31 & 31 \\
\hline \multicolumn{4}{|l|}{ peridotite } \\
\hline Minimum value (Min) & 1.9 & 2050 & 152 \\
\hline Maximum value (Max) & 100.0 & 66600 & 2235 \\
\hline Mean value (Mean) & 31.2 & 21926 & 1082 \\
\hline Standard deviation (Std dev) & 34.5 & 21361 & 676 \\
\hline Number of samples (n) & 7 & 7 & 7 \\
\hline \multicolumn{4}{|l|}{ conglomerate } \\
\hline Minimum value (Min) & 5.2 & 1700 & 124 \\
\hline Maximum value (Max) & 76.0 & 41800 & 962 \\
\hline Mean value (Mean) & 25.5 & 13043 & 473 \\
\hline Standard deviation (Std dev) & 13.9 & 11117 & 264 \\
\hline Number of samples (n) & 21 & 21 & 21 \\
\hline \multicolumn{4}{|l|}{ sandstone } \\
\hline Minimum value (Min) & 13.5 & 3420 & 120 \\
\hline Maximum value (Max) & 205.7 & 71750 & 727 \\
\hline Mean value (Mean) & 80.9 & 26364 & 371 \\
\hline Standard deviation (Std dev) & 56.4 & 17481 & 164 \\
\hline Number of samples (n) & 36 & 36 & 36 \\
\hline \multicolumn{4}{|l|}{ limestone } \\
\hline Minimum value (Min) & 11.8 & 4700 & 160 \\
\hline Maximum value (Max) & 243.9 & 254470 & 1445 \\
\hline Mean value (Mean) & 89.7 & 71868 & 766 \\
\hline Standard deviation (Std dev) & 56.8 & 59194 & 323 \\
\hline Number of samples (n) & 101 & 101 & 101 \\
\hline \multicolumn{4}{|l|}{ granite - gneiss } \\
\hline Minimum value (Min) & 15.9 & 2590 & 147 \\
\hline Maximum value (Max) & 116.6 & 88790 & 865 \\
\hline Mean value (Mean) & 64.8 & 31874 & 455 \\
\hline Standard deviation (Std dev) & 37.8 & 27410 & 285 \\
\hline Number of samples (n) & 13 & 13 & 13 \\
\hline
\end{tabular}

\section{Test results - correlations between rock properties}

The values of the determined elastic and strength rock material properties are summarized in Table 1. As it shown in Table 1, the MR values for tested rock specimens range as follows: 134 to 920 for 

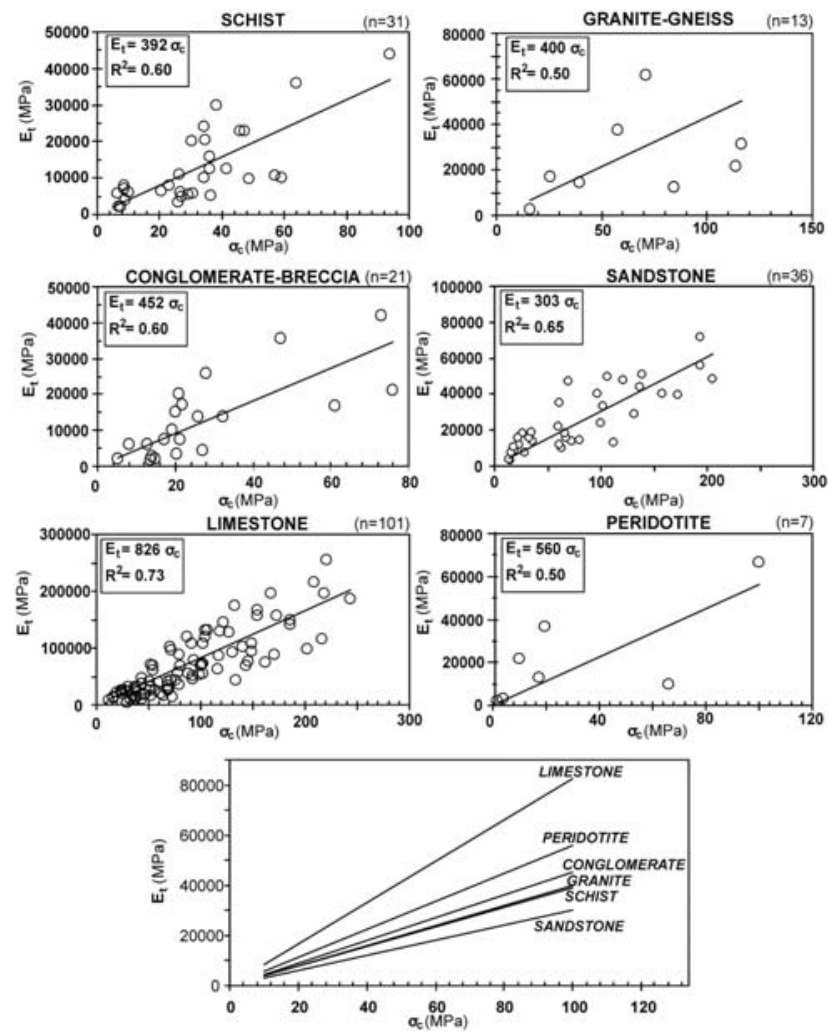

Fig. 1: Correlation between elastic Young's modulus $\mathrm{E}$ and uniaxial compressive strength $\sigma_{\mathrm{c}}$ for various rock material.

schist (loading perpendicular to weakness plane), 152 to 2235 for peridotites, 124 to 962 for conglomerate, 120 to 727 for sandstone, 160 to 1445 for limestones, and 147 to 865 for granite.

Regression analysis was applied to define the relation among elastic rock properties. The regression procedure was to fit a line through the points, which is computed so that the squared deviations of the measured points from that line are minimized. The line in a two-variable space was defined by the relevant equation, whereas the value of coefficient of determination or R-square value was also determined. The R-square value is an indicator of how well the model fits the data.

Comparing the determined MR values with those suggested by Hoek and Diederichs (2006), it is concluded that the MR values of the specimens tested and especially peridotite present a greater range.

Moreover, the relationships between $\mathrm{E}_{\mathrm{t}}$ and UCS for rock specimens tested are expressed by the equations (Fig. 1):

$$
\begin{aligned}
& E t=392 \cdot \sigma_{c} \text { for schist }\left(\mathrm{E}_{\mathrm{t}}: \mathrm{MPa}, \sigma_{\mathrm{c}}: \mathrm{MPa}\right), \mathrm{R}^{2}=0.60 \\
& E t=400 \cdot \sigma_{c} \text { for granites }- \text { gneiss }\left(\mathrm{E}_{\mathrm{t}}: \mathrm{MPa}, \sigma_{\mathrm{c}}: \mathrm{MPa}\right), \mathrm{R}^{2}=0.50 \\
& E t=452 \cdot \sigma_{c} \text { for conglomerate }- \text { breccia }\left(\mathrm{E}_{\mathrm{t}}: \mathrm{MPa}, \sigma_{\mathrm{c}}: \mathrm{MPa}\right), \mathrm{R}^{2}=0.60 \\
& E t=303 \cdot \sigma_{c} \text { for sandstones }\left(\mathrm{E}_{\mathrm{t}}: \mathrm{MPa}, \sigma_{\mathrm{c}}: \mathrm{MPa}\right), \mathrm{R}^{2}=0.65 \\
& E t=826 \cdot \sigma_{c} \text { for limestones }\left(\mathrm{E}_{\mathrm{t}}: \mathrm{MPa}, \sigma_{\mathrm{c}}: \mathrm{MPa}\right), \mathrm{R}^{2}=0.73 \\
& E t=560 \cdot \sigma_{c} \text { for peridotites }\left(\mathrm{E}_{\mathrm{t}}: \mathrm{MPa}, \sigma_{\mathrm{c}}: \mathrm{MPa}\right), \mathrm{R}^{2}=0.50
\end{aligned}
$$


The above estimated relations for limestone and sandstone (eq. 4 and 5) are quite similar to those previously suggested by Sabatakakis et al (2009). It is noted that the eq. 5 in this study include a complementary number of about fifteen data pairs.

Tuğrul and Zarif (2000) suggested similar linear function for limestones, while power functions have been reported by Duncan and Dunne (1967), Dearman and Irfan (1978), Irfan and Powell (1985), Turk et al. (1994), Gupta and Rao (2000) for igneous, metamorphic and sedimentary rocks having different degree of weathering.

\section{Conclusions-Results}

The evaluation of strength and deformability parameters of rocks obtained by laboratory test results led to the establishment of regression equations among elastic rock properties. A linear function exists between Young's modulus and unconfined compressive strength with RM values ranging a lot. The mean MR values for tested rock specimens are as follows: 392 for schist (loading perpendicular to weakness plane), 560 for peridotites, 452 for conglomerate, 303 for sandstone, 826 for limestones, and 400 for granite. The variability of deformability parameters is mainly related to the textural characteristics and composition changes of the rock material.

\section{References}

American Society for Testing and Materials, 1993. Standard test method for elastic moduli of intact rock core specimens in uniaxial compression, Annual Book of Standards.vol. 04.08, D3148-93.

Dearman, W.R., Irfan, T.Y.,1978. Assessment of the degree of the weathering in granite using petrographic and physical index tests. Proc. of the International Symposium on Deterioration and Protection of Stone Monuments, Unesco, Paris, pp 1-35, paper 2.3.

Deere, D.U., Miller, R.P.,1967. Engineering classification and index properties for intact rocks. Tech. Rep. No. AFWL-TR-65-116. University of Illinois, Urbana. 229p.

Duncan, N., Dunne, M.H., 1967. A regional study of the development of residual soils. Proc. of the 4th African Regional Conference on Soil Mechanics Found. Engineering, Cape Town, pp. 109-119.

Gupta, A.S., Seshagiri Rao, K., 2000. Weathering effects on the strength and deformational behaviour of crystalline rocks under uniaxial compression state. Engineering Geology, 56, pp. 257-274.

Hoek, E., Diederichs, M.S., 2006. Empirical estimation of rock mass modulus. International Journal of Rock Mechanics and Mining Sciences, 43, pp. 203-215.

Irfan, T.Y., Powell, G.E., 1985. Engineering geological investigations for pile foundation on a deeply weathering granitic rock in Hong Kong. Bulletin of the association of Engineering Geology, 32, pp. 67-80.

ISRM Suggested Methods, 1981. Suggested methods. Rock characterization, testing and monitorring, ed. E.T. Brown, Pergamon Press, Oxford.

Sabatakakis, N., Koukis, G., Tsiambaos, G., Papanakli, S., 2008. Index properties and strength variation controlled by microstructure for sedimentary rocks. Engineering Geology,11.

Tugrul. A., Zarif, I.H., 2000. Engineering aspects of limestone weathering in Istanbul, Turkey. Bulletin of Engineering Geology and the Environment, 58 (3), pp. 191-206.

Turk, N. Koca, M.Y., Yuzer, E., Qztas, T., Erdogan, M., 1994. Engineering geological problems of the first phase of the Izmir Metro. Proc. of the 7th International IAEG Congress. Lisbon.Balkema. Rotterdam. pp. 4259-4264. 